\title{
BOUNDS FOR THE RATIO AND DIFFERENCE BETWEEN PARALLEL SUM AND SERIES VIA MOND-PEČARIĆ METHOD
}

\author{
J. I. FujiI, M. NAKAmura, J. PeČARić AND Y. SEO
}

Abstract. Upper bounds for the ratio and the difference between parallel sum and series of operator connections in the sense of Anderson-Duffin-Trapp are obtained, in which the MondPečarić method for convex functions is applied: Let $A$ and $B$ be positive operators on a Hilbert space such that $0<m I \leqslant A, B \leqslant M I$ for some scalars $m<M$. Then we show an upper bound of the difference of parallel sum and series :

$$
(A+B)-(A: B) \leqslant 2(M+m-\sqrt{M m}) I .
$$

As an application, we show a noncommutative Kantorovich inequality: For positive operators $A$ and $B$ such that $0<m I \leqslant A, B \leqslant M I$,

$$
\frac{A+B}{2} \leqslant \frac{(M+m)^{2}}{4 M m}\left(\frac{A^{-1}+B^{-1}}{2}\right)^{-1}
$$

and moreover we show the following refinement:

$$
\frac{2 \sqrt{M m}}{M+m} \frac{A+B}{2} \leqslant A \sharp B \leqslant \frac{M+m}{2 \sqrt{M m}}\left(\frac{A^{-1}+B^{-1}}{2}\right)^{-1},
$$

where $A \sharp B$ is the geometric mean.

Mathematics subject classification (2000): 47A30, 47A63.

Key words and phrases: Kantorovich inequality, Kantorovich constant, operator inequality, parallel sum, operator connection, positive linear map and Mond-Pečarić method.

\section{REFERENCES}

[1] W. N. Anderson, R. J. Duffin, Series and parallel addition of matrices, J. Math. Anal. Appl., 26, (1969), 576-594.

[2] W. N. Anderson, G. E. TRAPP, Shorted operators II, SIAM J. Appl. Math., 28, (1975), 60-71.

[3] T. ANDO, Concavity of certain maps on positive definite matrices and applications to Hadamard products, Linear Algebra Appl., 26, (1979), 203-241.

[4] T. Furuta, J. MićIĆ, J. E. PeČARIĆ AND Y. SEO, Mond-Pečarić Method in Operator Inequalities, Monographs in Inequalities 1, Element, Zagreb, 2005.

[5] T. FURUTA, J. PEČARIĆ, An operator inequality associated with the operator concavity of operator entropy $A \log A^{-1}$, Math. Inequl. Appl., 6, (3) (2003), 531-543.

[6] L. V. KANTOROVICH, Functional analysis and applied mathematics (in Russian), Uspechi Mat. Nauk., 3, (1948), 89-185.

77] F. KuBO, T. ANDO, Means of positive linear operators, Math. Ann. 246, (1980), $205-224$.

[8] B. Mond, J. E. PEČARIĆ, Converses of Jensen's inequality for linear maps of operators, Analele Universităţii din Timişoara, 31, (1993), 223-228.

[9] J. E. PEČARIĆ, J. MićIĆ, Chaotic order among means of positive operators, Sci. Math. Japon. Online, 7, (2002), 97-106. 